\title{
Solothurn 2001
}

\author{
By Andrzej Gwóźdź
}

Fall 2001 Issue of KINEMA

\section{SOLOTHURN: NEAR DAVOS}

As the red-hot television and press were condemning the authorities' decision to enclose the World Economic Forum in a police ghetto and Zurich was lit by burning cars, Mathias Knauer was throwing curses upon the "global fascist market" and was sending the "holy market" of capitalism to hell. It seemed as though the Davos syndrome was spreading over the XXXVI Solurian Film Days.

This is all connected with the documentary Bitterfeld, 1992, through which Knauer (born in 1942) invokes the nostalgia for the GDR prosperity of the East Germany's largest chemical plant confronted with the "new colonial economy" of the Federal Republic. Although initially slightly confused, the audience wants to believe the author's manifesto in the "possibility of a different from the capitalist) world" and rewards the movie with roaring applause. Knauer devised a state-of-the-art piece of propaganda -- by juxtaposing the glorious moments of the GDR's economy with its collapse during the "Kohl regime", he had "objectively" illustrated the price paid by Germany for the nation's unification. All this pseudo-argumentation becomes apparent, however, when Knauer shows the factory's ancient infrastructure, which dates back to the times of the First World War. Yet even there, he praises the industrious inventiveness of the GDR's working class which was able to maintain the functioning of the long outdated machinery.

Apart from this, the Solothurn mixture was devoid of further such revelations. It seems that the Swiss are tired of dabbling in politics. After the last year's penance for the attitude of the Helvetians towards the Jews during Word War II and after the recovery from the hangover which had been troubling the nation for several years as an aftermath of the Swiss "no" for the European Union, upon the banks of lazy Araa was an atmosphere of tranquility and fun, seldom disturbed by any signs of moral unease.

Those rare states of discomfort were largely incited by Kaspar Kasics and his documentary Blue End, enthusiastically received by the audience starving for such thrills. The matter concerns a murderer and the ambiguous death sentence carried out in 1993 in Huntsville, Texas. However, the main burning issue is about the employment of the body as a material for a computer simulation of a human organism. Only a year and a half after the execution, Joseph Paul Jernings appeared on the internet: thanks to the efforts of the Medical Centre of the University of Colorado in Denver, the first fully digitised man was born, in a way a prototype of human anatomy (http://www.nlm.nih.gov/). Instead of eight and a half million pages of text about the human organism -- 15 gigabytes of data composed of precisely peeled back layers of the murderer's frozen body, photographed millimetre by millimetre. Kasics shows the moral aspect of the "Visible Man" project which enables a resurrection in a digital anatomy book on computer screens (the employment of a human body without the knowledge of its "owner") and also traces, step by step, the fascination of scientists who calmly discuss the technology of body preservation not only for the purpose of science but also for computer games and perhaps in the near-future for movie plots. Both those factors present a dramatic picture of life after death, one already noted in the past by media theoreticians.

No wonder then, that a story of a good grandpa (played by Paolo Villaggio, whose very appearance is enough to make one shed a tear) and his blind granddaughter, who travel from the far Apulia to Geneva in search of finances for the child's operation is a sight for sore eyes and wraps around one's heart like grandmother's warm scarf. Azzurro by Italian Denis Rabaglia (Swiss-Italian-French co-production) has all the good and bad qualities of a classic tear jerker. The movie would have passed unnoticed if it were not for what we all like so much in cinema: observing from a safe distance our positive and negative national qualities. The amiable grandpa had worked in Switzerland as a Gastarbeiter for the best thirty years of his life and wants now something in return -- not for himself but for his beloved granddaughter. After numerous disappointments and troubles (grandpa has a weak heart) everything ends happily and little Carla is able to discover the world anew to the rhythm of Adriano Celentano's smash hit. The movie received a Film Award for the year 2001 in the best plot category and the viewers were finally satisfied. 
The affiliation with the poetics of a road movie was also displayed by Nicolas Wadimoff, who was born to a Russian-Italian family and educated in Canada. Mondialito (a Swiss-French co-production) tells a story of difficult friendship between two outsiders -- an orphanage runaway Latino and an Algerian. What brings them together is a mutual obsession with football, a passion for which the Algerian had already almost paid with his life. As the semi-finals of the World Cup are approaching, little Abdou is desperate to see with his own eyes the match between Brazil and France, to be played out in the remote Marseilles. The man and the boy thus venture together along the Highway of the Sun to witness the wondrous semi-finals. And a road is a road -- always full of surprises and adventures, of which Wadimoff speaks in a jocular but wise manner. Yet the film also tells of the other, inner journey, the coming to one's identity as well as, quite literally and without obtrusive metaphors or didacticism, of coming home, as the protagonist's family lives in Marseilles. The finale of the film, where Ahmed with his family by his side is watching the semi-finals transmission and suddenly glimpses Abdou's elated face on the TV screen, was one of the most beautiful of the whole festival.

Similar yet certainly easier optimism shines out from the tale Pane e tulipani by Silvio Soldini, who out of a banal story of a brief affair set against the Venetian canals managed to distil so much psychological truth and human warmth that he was nominated for the Film Award. Although the movie, a Swiss-Italian coproduction, was itself not awarded, the award for the best actor went to Bruno Ganz, an artist beloved here and seen to perform in Swiss productions more often than in German ones. Camera work of Luki Bigazzie seems to be able to cast a refreshing light upon an apparently totally exploited image of Venice, which allows one to perceive the less tame inner side of the city's countenance. The thing concerns a liaison of a mature wife and mother who imperceptibly and almost unintentionally engages in a successful and mutual love affair (Ganz as the lover). Everybody benefits, apart from the unpleasant husband who is brutally and bluntly brushed aside. The film turned out to be a box office hit in Swiss cinemas -- a rare occasion when it comes to indigenous movies -- over 240 thousand viewers!

A completely different mood is offered by a lavish historical family saga Les destinées sentimentales by Olivier Assayas, an adaptation of Jacques Chardonne's novel. The story of a preacher who having abandoned his wife, married into a clan of porcelain manufacturers from Limoges, renders a large piece of French history of the first thirty years of the twentieth century and Assayas narrative enchants the viewer with its sophisticated serenity, a phenomenon rare in contemporary cinema. The film impresses with its excellent although perhaps too gaudy acting (with the superb Emmanuelle Béart, Isabelle Huppert and marvellous Charles Berling leading the way) and the exquisite, almost documentary-like realism (reconstruction of the production process of porcelain and cognac!).

But all this is skilfully subordinated to the holistic aesthetics of the work and without regret allows one to breathlessly follow for three full hours the fates of a family thrown into the flow of great History. I, however, most liked a story of a certain long holiday of an anti-fascist writer, journalist and social critic Kurt Tucholsky (his books were among the first to go in the bonfire on the Opera Square in Berlin in 1933), spent in a Swedish castle, Gripsholm. Xavier Koller, who had received an Oscar in the best foreign picture category for his Hopeful journey ten years ago (since then he has been living and working in Los Angeles), was now nominated for the American Academy Award. Gripsholm is a story of a seemingly carefree holiday, which ends tragically, however, with the writer's suicide in Sweden, separated from the Nazi Germany by the Baltic Sea. Yet even there, and not only through the press, do the echoes of the fascist politics reverberate. An ardent pilot Karchlen appears like a herald of the Apocalypse on Gripsholm's clear sky, a man who once was Tucholsky's friend and now is a fanatical supporter of Hitler. In the nearby boarding schools, the teachers adopt methods better suited for a concentration camp.

The film's appeal is based on a harmonious combination of various moods -- from political horror to an atmosphere of decadence. Here Koller seems to inherit the tradition of Bob Fosse's Cabaret. The movie speaks of cabaret as well, but when much was allowed, although through the window panes one could see the Jewish shop windows smashed and the synagogues burn. Slightly lustreless Ulrich Noethen as Tucholsky is accompanied by dashing Heike Makatsch, not so long ago a teenage idol from German RTL II and Viva, who has already made a significant appearance starring in several German movies.

It would seem that the Swiss try to avoid their national problems and dilemmas, directing the storylines towards bordering countries. The point is, and it has been so in Solura for several years, that those movies are 
profoundly European, international and simply made also with Swiss money. Those movies could have just as well been presented to the audience of the co-producing countries. In spite of this, there were also movies embedded in Swiss reality, such as Komiker by Markus Imboden -- an unpretentious comedy about the feats of an old folk's home residents. In terms of cinema, the Swiss "no" to united Europe placed Switzerland in the very middle of the old continent. And it does her well.

\section{Author Information}

Andrzej GWÓŹDŹ is Professor at the Silesian University in Katowice (Poland). His professional interest focuses on film theory and problems of electronic media. A noted film theoretician in his country, Prof. Gwóźdź has held visiting posts at academic institutions in Germany, Austria and Holland. He is the author of nine books on film theory, including the groundbreaking anthology Filmtheorie in Polen (1992). 